\title{
Content of copepod faecal pellets in relation to food supply in Kiel Bight and its effect on sedimentation rate
}

\author{
Maren Voss \\ Institut für Meereskunde an der Universität Kiel, Düsternbroker Weg 20, W-2300 Kiel, Germany
}

\begin{abstract}
The content of suspended and sedimented copepod faecal pellets in relation to phytoplankton stocks was investigated in Kiel Bight in summer 1986. Sedimentation rates of faecal pellets were also measured using sediment traps. Parallel to the field investigation, incubations were conducted in which the dominant copepods, Acartia sp. and Centropages hamatus, were fed with natural phytoplankton. Faecal pellets from field samples and laboratory experiments were analyzed by scanning electron microscopy. Results showed a strong relationship between the composition of ambient food supply, ingested phytoplankton and faecal pellet content. In addition, faecal pellet sedimentation rates in July and August (4400 and $7700 \mathrm{~m}^{-2} \mathrm{~d}^{-1}$ respectively) differed from those in September (168 $\left.000 \mathrm{~m}^{-2} \mathrm{~d}^{-1}\right)$. This was attributed to the change in phytoplankton composition, which consisted mainly of athecate flagellates in July and August but was dominated in September by Prorocentrum minimum, a thecate dinoflagellate.
\end{abstract}

\section{INTRODUCTION}

Copepod faecal pellets contain dietary remains, which can be used to identify the various food items ingested. Food such as naked flagellates may be traced in the faecal pellets by chemical analysis such as pigment measurements (Bathmann \& Liebezeit 1986). More specific information, even on the species level, can be obtained microscopically from faecal pellets containing remnants of hard-shelled organisms e.g. tests, thecae and valves (Turner \& Ferrante 1979, Turner 1984b, c, 1986, Turner \& Tester 1989). Besides providing information on food items, the content and morphology of faecal pellets - as for aggregates in general - is crucial to their potential sinking speed (Alldredge \& Gotschalk 1988). Pellets containing diatom frustules have a considerably higher sinking velocity than those filled with the remains of naked flagellates (Smayda 1969, Bienfang 1980). Because of their high potential sinking speed, faecal pellets have been discussed as the main transport vehicles for organic matter out of the upper layer of the ocean and to the sea floor (Honjo \& Roman 1978, Angel 1984). However, Pilskaln \& Honjo (1987) found in deep-sea sediment traps that faecal pellets may contribute only a minor portion to total vertical flux.
Seasonal and regional differences in pellet flux have been reported. During spring, high vertical flux rates in Bransfield Strait, Antarctica, were attributed almost exclusively to rapidly sinking krill faeces (von Bodungen 1986). Bathmann et al. (1987) and Peinert et al. (1987) reported from the Norwegian Sea that zooplankton retarded the downward flux of faecal pellets. The mechanism driving these differences in faecal pellet sinking behaviour might be reingestion, or coprophagy (Paffenhöfer \& Knowles 1979). Production of gas inside the peritrophic membrane of the pellets, leading to reduced sinking velocities, has been speculated upon by Krause (1981) and Smetacek (1980), thus possibly increasing the residence time of faecal pellets in the water column. Lampitt et al. (1990) have proposed coprorhexy, the fragmentation of faecal pellets by zooplankton, as a possible method of reducing sedimentation rates. Most recently Noji et al. (1991) have shown that the morphological loosening of faecal material, coprochaly, also can significantly decrease sinking velocities of pellets. Thus, regional and seasonal differences in the importance of faecal pellets to vertical transport are individually or collectively influenced by the content and biological modification of the pellets.

This investigation focuses on the effects of seasonally 
differing food quality on the sinking of faecal pellets. Five times, from July through September, faecal pellets from the water column and a sediment trap in Kiel Bight, Western Baltic Sea, were analyzed. In addition the feeding behavior of the dominant copepod groups was studied in feeding experiments. Faecal pellets collected in situ and from the experiments were examined with a scanning electron microscope (SEM).

\section{MATERIAL AND METHODS}

A station in Kiel Bight was visited 5 times between 21 July and 8 September 1986 (Fig. 1). Temperature and salinity from surface to bottom $(27 \mathrm{~m})$ were recorded with T/S sensors (WTW Conductometer LF 191) and water samples above and below the pycnocline were taken with 10 I Niskin bottles for phytoplankton identification. Ninety liters of water was collected with a rosette sampler fitted with $6 \times 30 \mathrm{l}$ bottles from each of the 2 discrete depths and the suspended faecal pellets were concentrated by gentle filtration through a $20 \mu \mathrm{m}$ net. All samples were preserved with buffered formaldehyde to a final concentration of $1 \%$. Zooplankton was collected in vertical tows with a $200 \mu \mathrm{m}$ net (opening diameter $16.6 \mathrm{~cm}$ ) from the pycnocline to the surface and from the bottom to the surface. Samples were preserved with buffered formaldehyde to a final concentration of $4 \%$. Zooplankton was identified with a dissecting microscope to genus level at 60 to $250 \times$ magnification.

A 'Kiel funnel'-type sediment trap (Zeitzschel et al. 1978) with an opening diameter of $31 \mathrm{~cm}$ was moored at $16 \mathrm{~m}$ water depth, $10 \mathrm{~m}$ above the sea bottom. Sedimented material was preserved in situ with chloroform. After recovery of the traps the samples were diluted, divided into subsamples, and additionally preserved with buffered formaldehyde to a final concentration of about $1 \%$. Samples were analyzed from 3 collecting intervals (23 Jul to 8 Aug, 8 to 15 Aug, 1 to 8 Sep).

Faecal pellets were counted with an inverted microscope, and prepared for the SEM by pipetting onto Nuclepore filters followed by dehydration in an alcohol-water dilution series. As destruction of the peritrophic membranes was desirable, critical-point drying was not conducted. The filters were coated with carbon and additionally with gold-palladium and

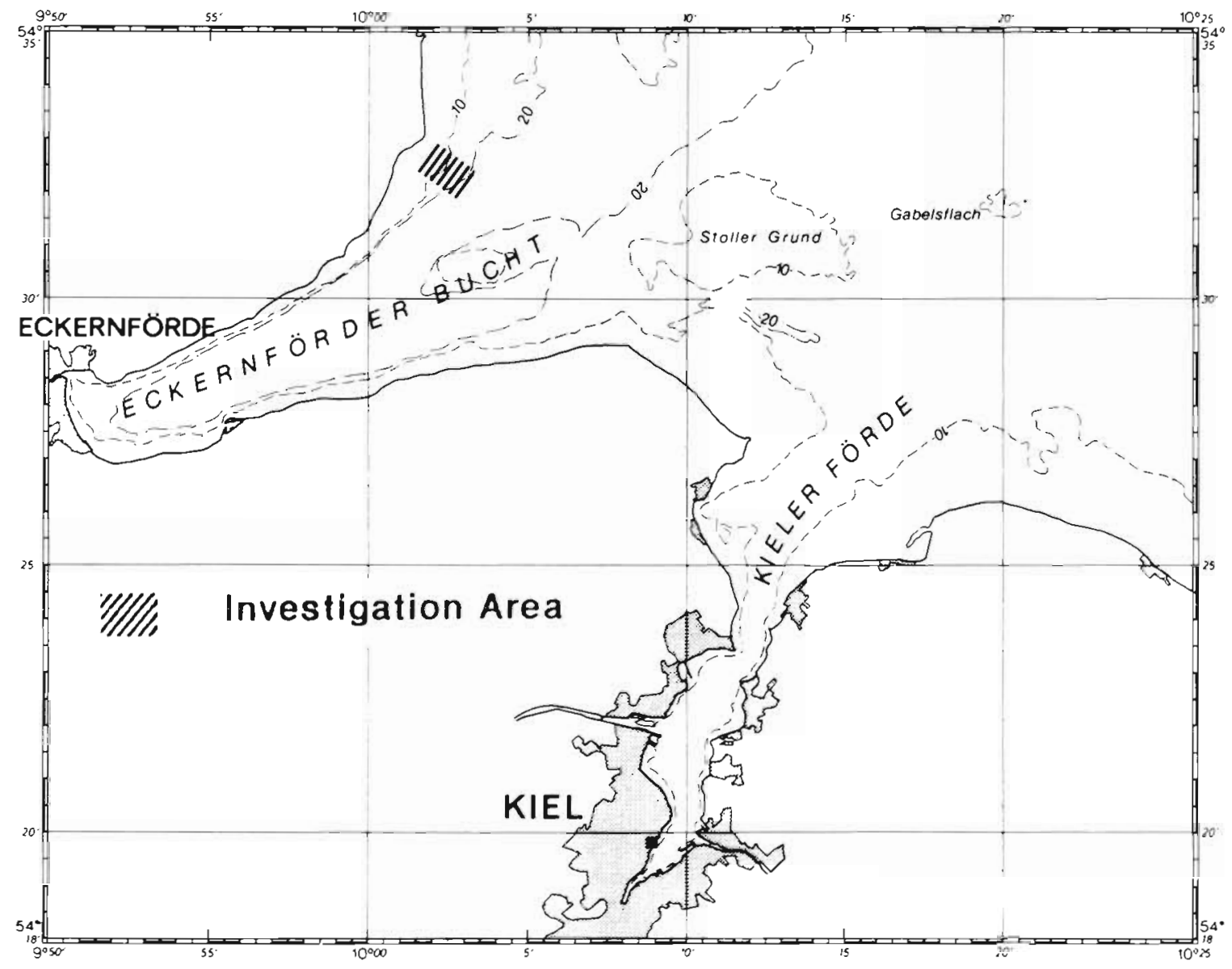

Flg. 1 Investigation area in the Kiel Bight (Western Baltic Sea) 
Table 1 List of experiments

\begin{tabular}{|lll|}
\hline Date & Incubated species & Origin \\
\hline $8 \mathrm{Aug}$ & Centropages hamatus & Surface water, $15 \mathrm{~m}$ depth \\
$8 \mathrm{Aug}$ & Acartia sp. & Surface water, $15 \mathrm{~m}$ depth \\
$11 \mathrm{Aug}$ & Centropages hamatus & Surface water, $15 \mathrm{~m}$ depth \\
$11 \mathrm{Aug}$ & Acartia sp. & Surface water, $15 \mathrm{~m}$ depth \\
$1 \mathrm{Sep}$ & Centropages hamatus & Surface water \\
$1 \mathrm{Sep}$ Acartia sp. & Surface water \\
$8 \mathrm{Sep}$ Centropages hamatus & Surface water \\
$8 \mathrm{Sep}$ Acartia sp. & Surface water \\
\hline
\end{tabular}

examined with a Cambridge S 150 electron microscope.

Phytoplankton species and faecal pellets were identified and counted with an inverted microscope (Zeiss) at 63 to $400 \times$ magnification (Utermöhl 1958). At this magnification and without staining or fluorescence techniques the determination of the number of small flagellates must be regarded as inaccurate. Since faecal pellets from calanoid copepods have a characteristic size and cylindrical shape they can be distinguished from other pellets, e.g. cyclopoid copepod pellets (Martens 1978) and many benthic faeces, e.g. from mussels (Arakawa 1970). Phytoplankton carbon was calculated from shapes and formulae given in Strathmann (1967) and Edler (1979).

Twelve feeding experiments with copepods were conducted (Table 1). Animals were collected with the same net type as described before. It was fitted with a closed cod-end and copepods were immediately sorted on board under a dissecting microscope. Ten to 20 copepods of the 2 important groups (Acartia sp. and Centropages hamatus) were placed in a faecal pellet

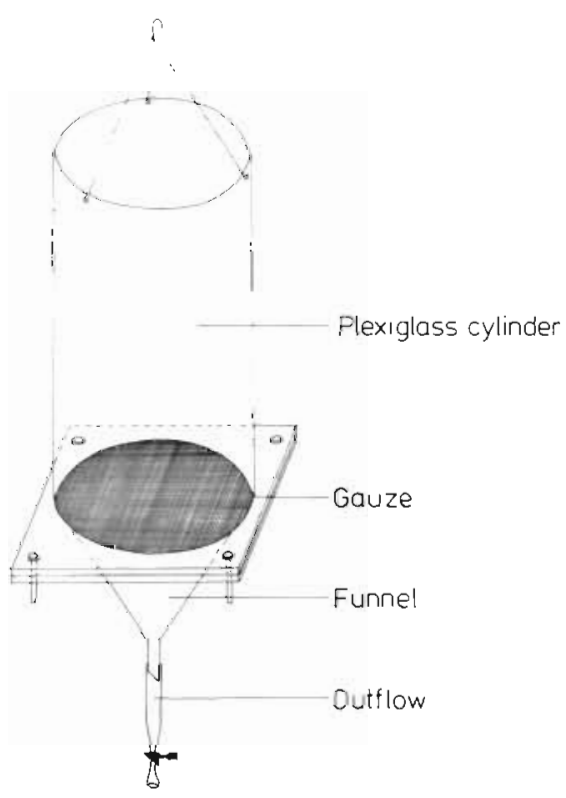

Fig. 2. Faecal pellet collector of 2 I volume. A removable PVC plate with gauze permits rapid changes of mesh size collector a plexiglas tube filled with 1 to 21 of seawater containing phytoplankton in natural concentrations (Fig 2). All experiments were carried out for $24 \mathrm{~h}$ in the dark at in situ temperature. Initial and final phytoplankton concentration and composition were determined by cell counts (Utermöhl 1958). Copepods were again identified and counted at the end of the experiment. The collected faecal pellets were prepared for SEM as described above. No controls were carried out, so phytoplankton mortality and microzooplankton grazing cannot be evaluated.

\section{RESULTS}

\section{Field data}

July. On 21 July 1986 the water column was stratified with a pycnocline ranging from 6 to $12 \mathrm{~m}$ depth. Phytoplankton biomass in the surface layer was about $93 \mu \mathrm{g}$ phytoplankton carbon (PPC) $1^{-1}$, dominated by athecate dinoflagellates $(<50 \mu \mathrm{m})$ with $73 \%$ of total PPC, and about $23 \mu \mathrm{g}$ PPC below the pycnocline with $62 \%$ athecate forms (Fig. 3A). Among the diatoms small centric and pennate species were most abundant in the upper water column whereas Skeletonema costatum and small Chaetoceros sp. could be found below the pycnocline, in $20 \mathrm{~m}$ depth.

The zooplankton population was made up by Pseudocalanus elongatus, Oithonasp. and Centropages hamatus in the upper water column and by Oithona sp. and $P$. elongatus alone below $8 \mathrm{~m}$ depth (Table 2 ).

The concentration of faecal pellets in the water column was $5800 \mathrm{~m}^{-3}$ above and $2900 \mathrm{~m}^{-3}$ below the pycnocline respectively, and 4400 pellets $\mathrm{m}^{-2} \mathrm{~d}^{-1}$ sedimented to $16 \mathrm{~m}$ depth (Fig. 4). Assuming no changes in the copepod population over the $16 \mathrm{~d}$ period, about 1 pellet sedimented per copepod $d^{-1}$. The content of faecal pellets from the water column from both sampled depths was very similar Only few remains of diatom valves could be identified, e.g. small Thalassiosira cells and intact pennate diatoms. All faecal pellets collapsed after dehydration for SEM, which indicated that they probably consisted largely of soft or water-soluble components (Fig. 5A). Only faecal pellets from the sediment traps did not show this effect; they contained mainly diatom debris.

August. On 8 and 11 August the pycnocline extended from 8 to $14 \mathrm{~m}$. There were again great differences in species composition between the 2 sampling depths (surface, $15 \mathrm{~m}$; Fig. 3B). On 8 August about $51 \%$ of the PPC in the surface waters were athecate dinoflagellates, about $13 \%$ were diatoms (mostly Skeletonema costatum) and $22 \%$ were small organisms, e.g. coccolithophorids and naked flagel- 
lates (Fig. 3B). Only one third of the carbon content of the surface layer $\left(105 \mu \mathrm{g}^{-1}\right)$ was found below the pycnocline $\left(35 \mu \mathrm{g} \mathrm{l}^{-1}\right)$. Most of it was attributable to Leptocylindrus danicus (10 $\mathrm{\mu g}$ PPC) and Prorocentrum minimum $(6.5 \mu \mathrm{g})$. Three days later, on 11 August, the phytoplankton composition was similar. However, PPC content increased to $230 \mu \mathrm{g} \mathrm{l^{-1 }}$ at $15 \mathrm{~m}$ depth. This increase was mainly made up by L. danicus ( $38 \%$ ) and athecate dinoflagellates (39\%; Fig. 3C). On 11 August almost all copepods were Acartia sp. and Centropages

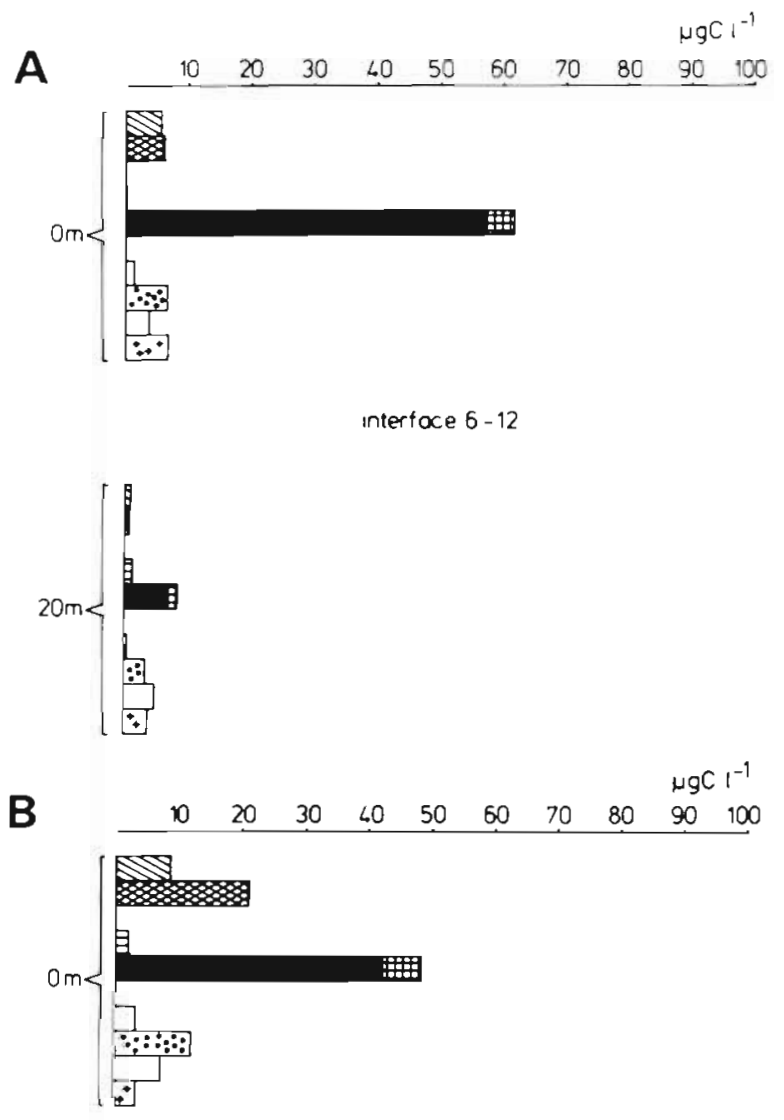

intertace $8-16 \mathrm{~m}$
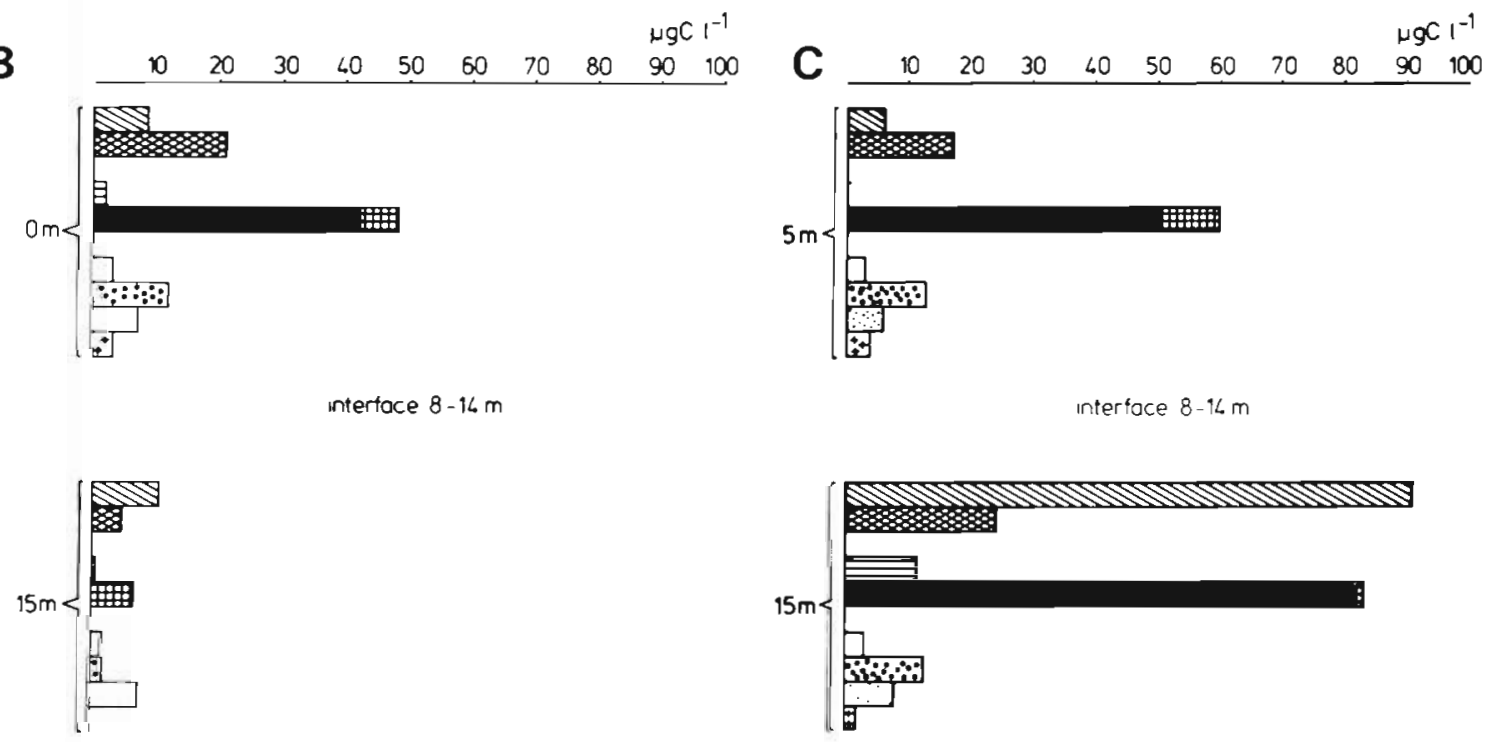

intertoce $8-16 m$

interface $8-14 \mathrm{~m}$

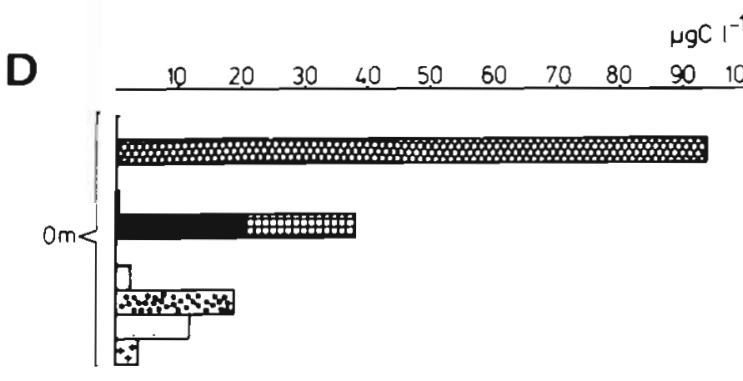

interface $10-18 \mathrm{~m}$
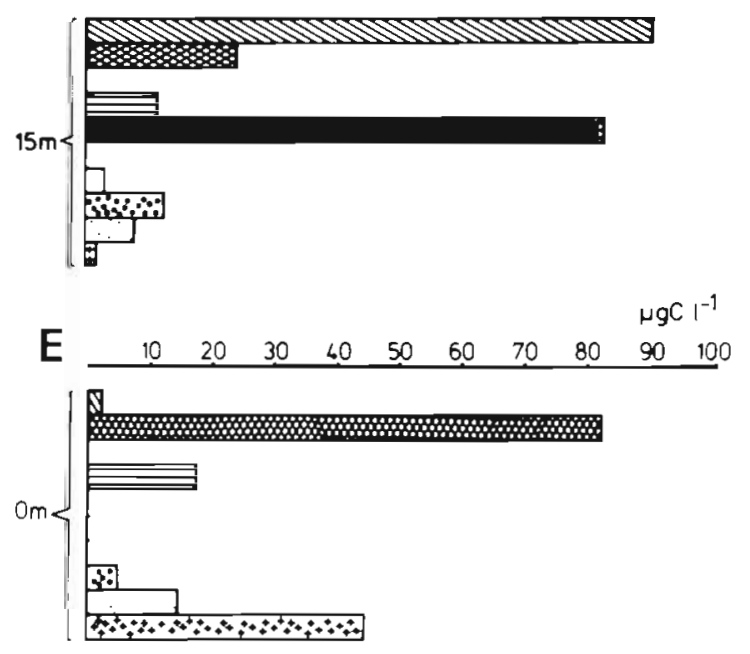

Interface $10-18 \mathrm{~m}$

Fig. 3. Phytoplankton concentration in 8 categories on the investigation days. (A) 21 July, (B) 8 August, (C) 11 August, (D) 1 September, (E) 8 September 1986 
Table 2. Copepod abundance (ind. $\mathrm{m}^{-3}$ per depth interval) on 21 July, 11 August and 1 September, from the 2 depth intervals above and below the thermocline

\begin{tabular}{|c|c|c|c|c|c|c|}
\hline & \multicolumn{2}{|c|}{21 July } & \multicolumn{2}{|c|}{11 August } & \multicolumn{2}{|c|}{1 September } \\
\hline & $8-0 \mathrm{~m}$ & $27-8 \mathrm{~m}$ & $10-0 \mathrm{~m}$ & $27-10 \mathrm{~m}$ & $9-0 \mathrm{~m}$ & $27-9 \mathrm{~m}$ \\
\hline Pseudocalanus elongatus & 87 & 145 & 9 & 7 & 36 & 10 \\
\hline Acartia sp. & 46 & 3 & 268 & 42 & 687 & 348 \\
\hline Centropages hamatus & 121 & 0 & 287 & 37 & 185 & 50 \\
\hline Oithona sp. & 156 & 59 & 0 & 17 & 36 & 0 \\
\hline
\end{tabular}

hamatus in the upper $10 \mathrm{~m}$; below this depth Pseudocalanus sp. comprised $42 \%$ of the adult calanoid copepod population (Table 2).

The faecal pellet concentration was lower in August than in July with 2400 and 2900 pellets $\mathrm{m}^{-3}$ above and below the pycnocline respectively. The sedimentation rate was slightly higher with 7700 faecal pellets $\mathrm{m}^{-2}$ $\mathrm{d}^{-1}$ and as in July about 1 pellet per copepod $\mathrm{d}^{-1}$ settled down to the trap depth. The SEM observations proved that the faecal pellets of the water column were not packed with hard parts. The recognizable debris originated from Prorocentrum minimum and some diatom species. Pellets from the greater depth $(15 \mathrm{~m})$ nearly kept their cylindrical shape because of the amount of fragmented diatom frustules, which presumably originated from Leptocylindrus danicus. The faecal pellets caught in the sediment trap contained remains of many different thecate species and were not as flat as the suspended ones. Most obvious were remains of $P$. minimum.

September. On 1 and 8 September the pycnocline extended from 10 to $18 \mathrm{~m}$, and the sediment trap was lacated within the pycnocline in $16 \mathrm{~m}$. The surface phytoplankton composition (Fig. 3D) differed from that of the previous month. Total PPC was 171 and $160 \mu \mathrm{g}$ respectively. Diatoms amounted to $2.1 \%$ and dinoflagellates to $77.5 \%$ (of total biomass on 1 September and to 8.1 and $51 \%$ respectively on 8 September (Fig. $3 \mathrm{D}, \mathrm{E})$. The dinoflagellates were dominated by Prorocentrum minimum and $P$. micans. These species were also found in the faecal pellets which were densly packed with dinoflagellate debris (Fig. 5B, C). The whole water column was dominated by Acartia sp. and Centropages hamatus and the numbers were double those found in the previous months (115 500 copepods $\mathrm{m}^{-2}$ ).

The number of suspended and sedimented faecal pellets also changed drastically. At $5 \mathrm{~m}$ there were 7800 , at 15 and $18 \mathrm{~m} 29200$ and 10800 faecal pellets $\mathrm{m}^{-3}$ respectively. There were about 22 faecal pellets suspended and 16 sedimented per copepod from the water column above the sediment trap. The sedimentation rate increased to 168000 faecal pellets $\mathrm{m}^{-2} \mathrm{~d}^{-1}$ (Fig. 4)

\section{Experiments}

Throughout the experiment the copepods seemed to be evenly distributed in the cylinders with a slight tendency to concentrate close to the gauze of the col-
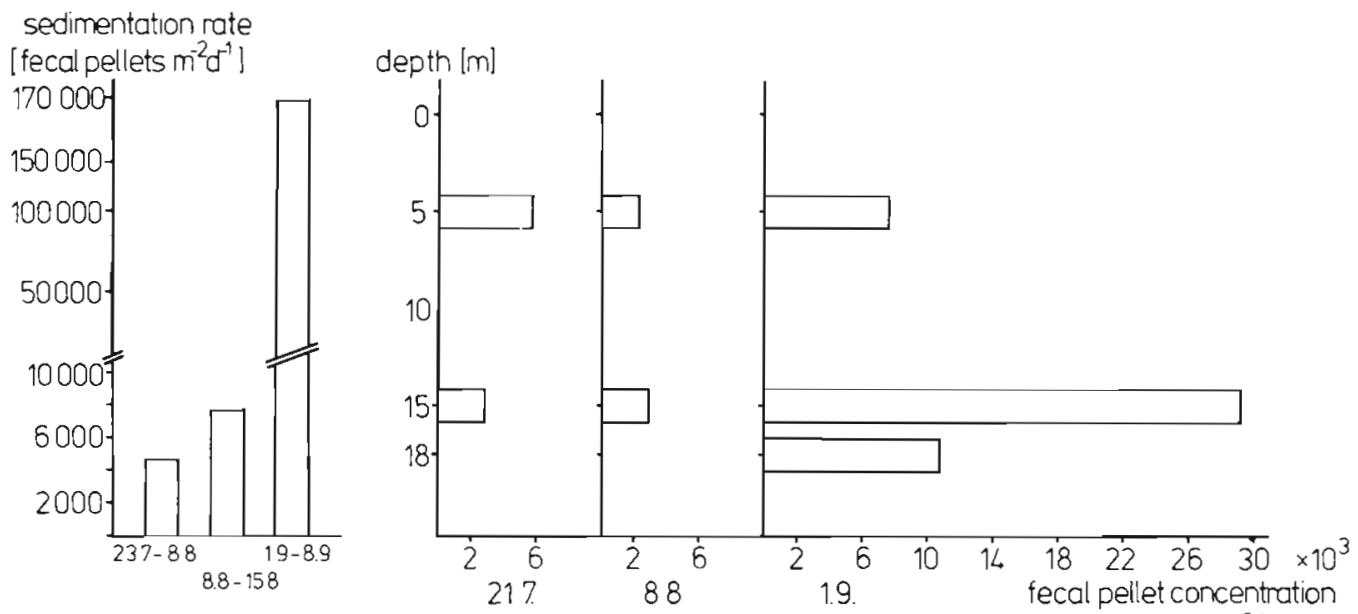

$\left[\mathrm{m}^{-3}\right]$

Fig. 4. Left: concentration of sedimented faecal pellets during the 3 collecting intervals; right: quantity of suspended faecal pellets. The thermocline was located between the 2 sampled depths in July and August and between 10 and $18 \mathrm{~m}$ in September 

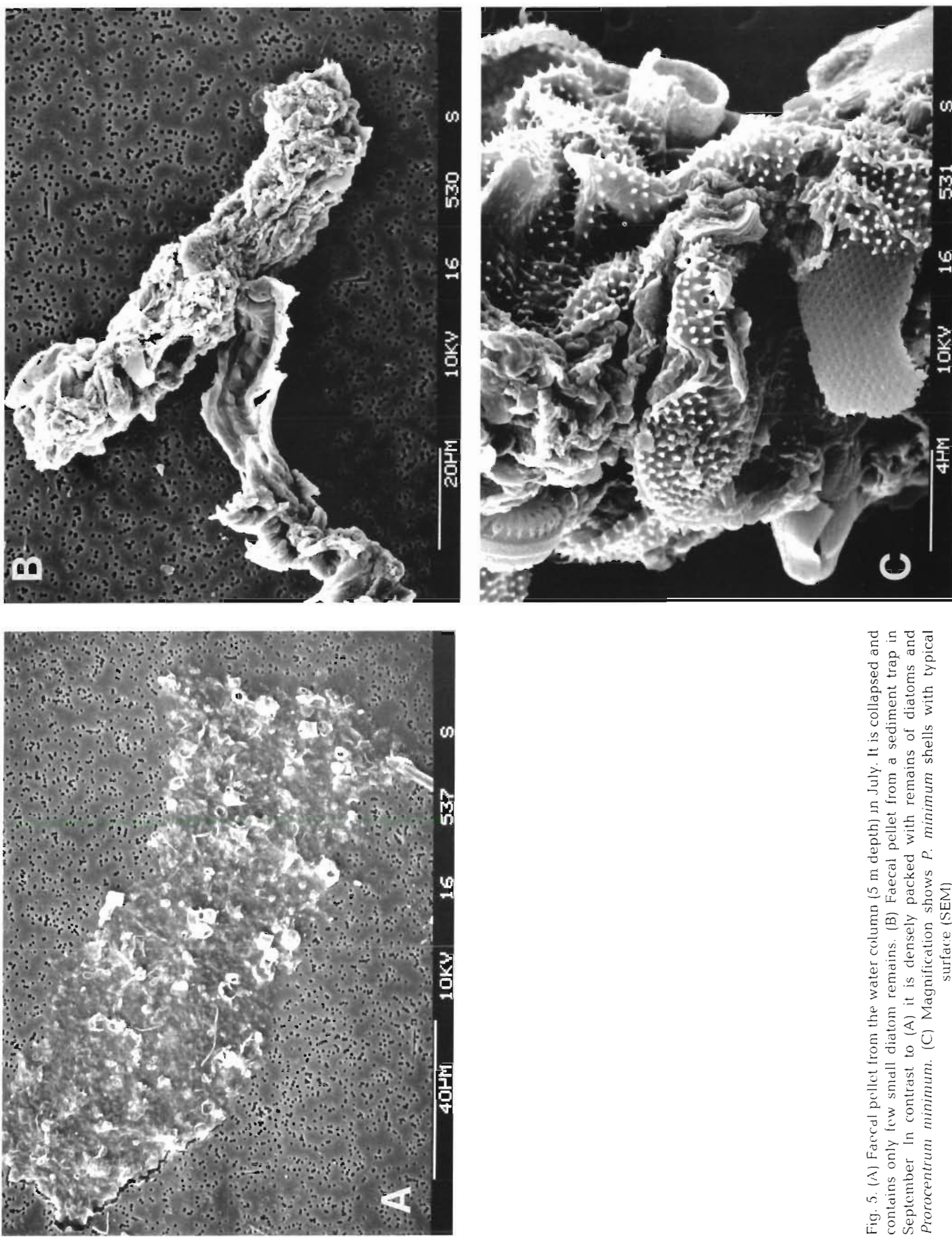

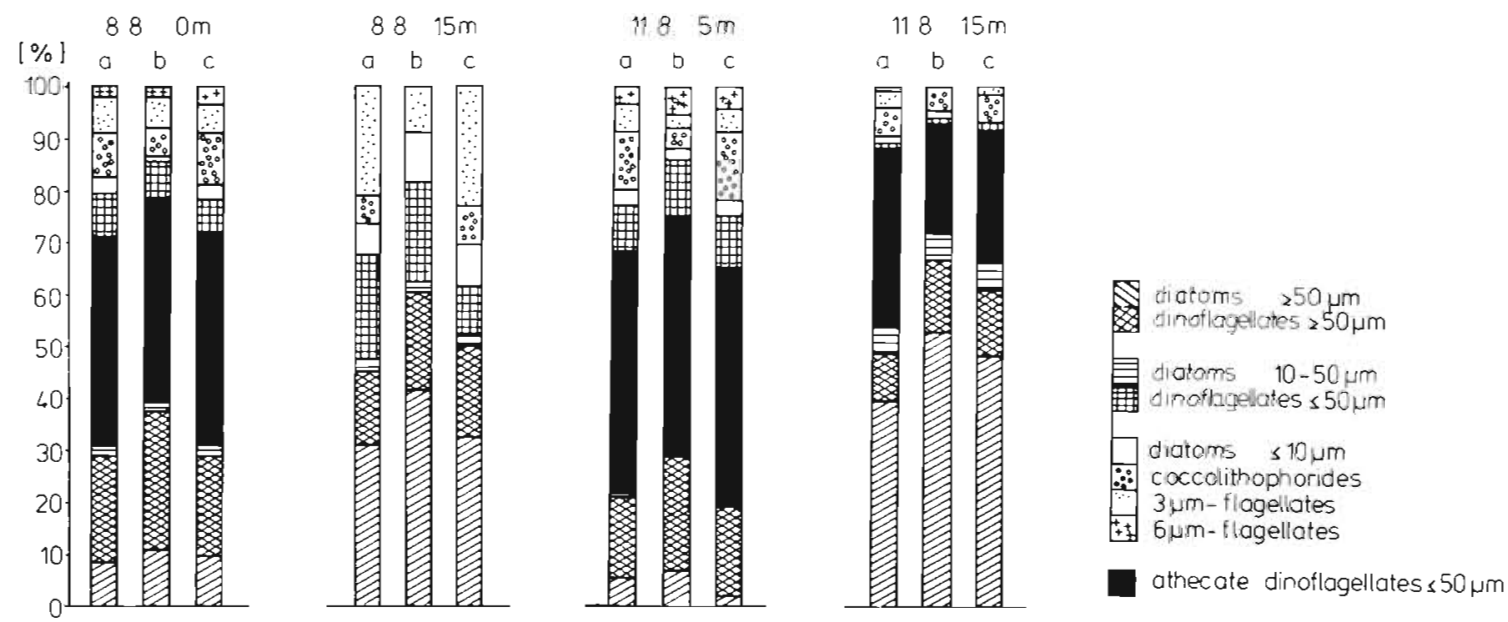

Fig. 6. Results of feeding experiments. a: Composition of phytoplankton offered to the copepods; b: ingested by Acartia sp.; c: ingested by Centropages hamatus

lectors. It was observed that cells $>50 \mu \mathrm{m}$ (Ceratium $\mathrm{sp}$. and others) were found in higher concentrations below the gauze at the end of the experiment due to sinking of these larger organisms. This might falsify the cell counts of the largest size fraction. However since this phenomenon occurred in all experiments comparisons are possible.

The feeding experiments in August and September showed only small differences in feeding behavior between the 2 species Acartia sp. and Centropages hamatus. The relative composition of phytoplankton $<10 \mu \mathrm{m}$ ingested by $C$. hamatus was very similar to that of the phytoplankton food supply. In contrast Acartia sp. seemed to prefer larger dinoflagellates and never ingested the small size fraction in the composition offered (Fig. 6) Both species fed phytoplankton organisms at nearly the composition offered (Fig. 6). Due to the large amount of athecate species, copepod pellets collapsed during the dehydration process. Only hardshelled organisms could later be identified by SEM.

\section{DISCUSSION}

The ecological significance of copepod faecal pellets - especially larger pellets from adults - lies in the potential transport of essential substances to deeper water layers (Honjo \& Roman 1978, Hofman et al. 1981, Urrère \& Knauer 1981, Gowing \& Silver 1983). On their way through the water column they may be degraded by microbial activity, and nutrient release occurs at great depths (Honjo \& Roman 1978, Jacobson \& Azam 1984). A new possibility has recently been discussed by Jumars et al. (1989) who postulate a rapid release of dissolved organic material while still in the euphotic zone. For shallow areas like the Kiel Bight, microbial degradation and the subsequent breakdown of faecal pellets in the water column has been speculated to be the primary mechanism preventing sedimentation of these particles (Smetacek 1980). That the food influences the sinking speed of faecal pellets has already been shown by Bienfang (1980) in laboratory experiments. However, this study describes the 'fooddependent sedimentation' of faecal pellets in situ.

The results of the feeding experiments verify that Acartia sp. and Centropages hamatus consumed nearly the same size spectrum of available food (Fig. 6). Both species are classified as omnivorous copepods (Anraku \& Omori 1963, Schnack 1982) and were presumably able to ingest the entire range of the phytoplankton population growing during the investigation time. Hence the faecal pellets of both species looked very similar, as also observed by Turner (1984a, b) and Turner \& Tester (1989). This is probably also true for faecal pellets of Pseudocalanus elongatus, the dominant copepod in July Schnack (1975) classified P. elongatus as a typical suspension feeder.

A simple calculation to compare the number of suspended, sedimented and theoretically (from literature data) produced pellets elucidates the sinking behavior' of the faecal pellets. There were about 75000 and 41000 faecal pellets suspended in the water column and about 3200 and 6500 calanoid copepods in July and August respectively (Table 3). Assuming a constant production rate for all 3 investigation days of 20 faecal pellets per copepod $\mathrm{d}^{-1}$ (Gamble 1978), the copepods must have produced ca 64000 faecal pellets in July, and 120000 in August. Of this assumed production only 6 to $7 \%$ were caught in the sediment trap in July and August. In contrast to this over 220000 pellets were produced in September $\mathrm{d}^{-1}$, of which over $70 \%$ were found in the trap in September (Table 3). So the question arises as to what happened to the bulk of the pellets in the months before? 
Table 3. Number of copepods, expected faecal pellet production rate (for calculation see text) measured flux rates and concentration of suspended pellets on the 3 investigation days. All values are integrated from surface to $16 \mathrm{~m}$ depth

\begin{tabular}{|c|c|c|c|c|}
\hline Date & $\begin{array}{c}\text { Concentration of } \\
\text { copepods } \\
{\left[\mathrm{m}^{-2}\right]}\end{array}$ & $\begin{array}{c}\text { Expected faecal } \\
\text { pellet prod } \\
{\left[\mathrm{m}^{-2} \mathrm{~d}^{-1}\right]}\end{array}$ & $\begin{array}{l}\text { No. of susp. } \\
\text { faecal pellets } \\
{\left[\mathrm{m}^{-2}\right]}\end{array}$ & $\begin{array}{l}\text { No. of sed. } \\
\text { faecal pellets } \\
{\left[\mathrm{m}^{-2} \mathrm{~d}^{-1}\right]}\end{array}$ \\
\hline $21 \mathrm{Jul}$ & 3216 & 64320 & 75400 & 4400 \\
\hline $11 \mathrm{Aug}$ & 6156 & 123120 & 41400 & 7700 \\
\hline 01 Sep & 11028 & 220560 & 235200 & 168000 \\
\hline
\end{tabular}

In July and August the food consisted of mostly athecate dinoflagellates and hence the pellets produced contained almost no identifiable planktonic remains. This has also been observed by Bathmann et al. (1987) for the Norwegian Sea in a situation where the food organisms were mainly small flagellates and a low sedimentation rate of faecal pellets was recorded. Smetacek (1980) found low faecal pellet concentrations in Kiel Bight in summer combined with relatively high copepod concentrations which led him to the conclusion that the residence time of faecal pellets in the water column must be much higher than supposed from laboratory sinking experiments. Smetacek (1980) and Bathmann et al. (1987) concluded that copepods retard the sedimentation of their faecal pellets through destruction. The likelihood of such a process has recently been confirmed by Lampitt et al. (1990) who described a copepod behavior called 'coprorhexy' - the fragmentation and ingestion of parts of the faecal pellets. Through longer residence times of faecal pellets and parts of them in the water column, the possibility of reingestion and degradation is enhanced. Noji et al. (1991) found a possible reduction in the sinking rate of copepod pellets of up to $50 \%$ due to 'coprochaly': loosening of faecal material.

Taking these investigations into consideration I speculate that the ingestion of athecate phytoplankton organisms leads to the production of fragile, sparsely packed faecal pellets which can easily be destroyed by turbulence and copepod feeding activity, especially due to their lower sinking velocities and, hence, longer residence time in the water column.

In September the faecal pellets from the water column, the sediment trap and the experiments were similar, and densely packed with remains of dinoflagellate thecae, the main food organism at that time. Therefore these pellets are probably more stable and have a higher specific weight than pellets from the month before. The high sedimentation pulse of $168000 \mathrm{~m}^{-2}$ $\mathrm{d}^{-1}$ was strongly influenced by the change of phytoplankton composition. This is supported by the following considerations: (1) The water column stratification had not changed. (2) The copepod species composition was roughly the same (compared to August). (3) The number of copepods had increased. Assuming that the faecal pellet production per individual had not changed, $70 \%$ sedimentation of the pellets is calculated. Even a doubling of the faecal pellet production rate - which cannot be excluded - would still result in sedimentation of more than $30 \%$ of the pellets produced. (4) Resuspension as source of additional pellets from the sediment can be excluded since no benthic diatoms or typical benthic pellets were found in the trap material.

Another interesting aspect is the composition of pellets collected in the sediment trap in July and August; they were always more densely packed with debris than the suspended ones. Those which sedimented during the first 2 collecting intervals were presumably heavier due to the larger content of diatom debris. These faecal pellets may have originated from feeding activities in subpycnocline waters where diatoms were more abundant. Suspended pellets contained less hard parts. This observation further supports a process of content-dependent sedimentation of copepod faecal pellets.

The content of copepod faecal pellets and thus their potential sinking speed is directly dependent on the diet of copepods. Experimental evidence for this has been reported by Bienfang (1980) and Smayda (1969). Besides the potential sinking speed, vertical export of particulate matter via faecal pellets in the field may be influenced by a variety of further factors. Among these are processes increasing the residence time of faecal pellets in the water column, such as reingestion, fragmentation and alteration of density (Krause 1981. Bathmann et al. 1987, Lampitt et al. 1990, Noji et al. 1991). The results presented here, however, describe a situation where a change in the dominance of naked to armored organisms in the phytoplankton population and consequently a change in the copepod diet appeared to exert the main influence on the substantially increased sedimentation of copepod faecal pellets. Thus, one may speculate that without a major change in grazing pressure a shift in the phytoplankton population can lead to an increased fallout of essential matter from the productive surface layer 
Acknowledgements. I thank my colleagues and friends from the 'SFB-Flur' for many stimulating discussions, especially Tom Noji, Uli Bathmann and Bodo von Bodungen. C. Samtleben and W. Reimann helped me with the SEM. I appreciate very much the helpful comments of Jefferson Turner and 2 anonymous reviewers. This is SFB publication No. 133, Sonderforschungsbereich 313 , University of Kiel

\section{LITERATURE CITED}

Alldredge, A. L., Gotschalk, C. (1988). In situ settling behavior of marine snow. Limnol. Oceanogr. 33: 339-351

Angel, M. V (1984). Detrital organic fluxes through pelagic ecosystems. In: Fasham, M. J. R. (ed.) Flows of energy and materials in aquatic ecosystems, NATO Conf. Ser. Vol. 13, Plenum Press, New York, London, 475-516

Anraku, M., Omori, M. (1963). Preliminary survey of the relationship between the feeding habit and the structure of the mouth-parts of marine copepods. Limnol. Oceanogr. 8: $116-126$

Arakawa, K. Y. (1970). Scatological studies of Bivalvia (Mollusca). Adv. mar. Biol.. 8: 307-436

Bathmann, U. V., Liebezeit, G. (1986). Chlorophyll in copepod faecal pellets: changes in pellet numbers and pigment content during a declining Baltic spring bloom. P.S.Z.N.I: Mar. Ecol. 7: 59-73

Bathmann, U. V., Noji, T. T., Voss, M., Peinert, R. (1987). Copepod faecal pellets: abundance, sedimentation and content at a permanent station in the Norwegian Sea in May/June 1986. Mar. Ecol. Prog. Ser. 38: 45-51

Bienfang, P. K. (1980). Herbivore diet affects faecal pellet settling. Can. J. Fish. Aquat. Sci. 37: 1352-1357

Bodungen, B. von (1986). Phytoplankton growth and krill grazing during spring in the Bransfield Strait, Antartica Implications from sediment trap collections. Polar Biol. 6: $153-160$

Edler, L. (1979). Recommendations on methods for marine biological studies in the Baltic Sea. BMB (Baltic Marine Biologists) Publ. 5: 1-38

Gamble, J. C. (1978). Copepod grazing during a declining spring phytoplankton bloom in the northern North Sea. Mar. Biol. 49: 303-315

Gowing, M. M., Silver, M. W. (1983). Origins and microenvironments of bacteria mediating faecal pellet decomposition in the sea. Mar Biol. 73: 7-16

Honjo, S., Roman, M. R. (1978). Marine copepod faecal pellets: production, preservation and sedimentation. J. mar. Res. 36: $45-57$

Hofmann, E. E., Klinck, J. M., Paffenhöer, G.-A. (1981), Concentrations and vertical fluxes of zooplankton faecal pellets on a continental shelf. Mar. Biol. 61:327-335

Jacobsen, T. R., Azam, F. (1984). Role of bacteria in copepod faecal pellet decomposition: colonization, growth rates and mineralization. Bull. mar. Sci. 35: 495-502

Jumars, P, A., Penry, D. L., Baross, J. A., Perry, M. J., Frost, B. W. (1989). Closing the microbial loop: dissolved carbon pathway to heterotrophic bacteria from incomplete ingestion, digestion and absorption in animals. Deep-Sea Res. 36: $483-495$

Krause, M. (1981). Vertical distribution of faecal pellets during FLEX 1976. Helgoländer Meeresunters. 34: 313-327

This article was submitted to the editor
Lampitt, R. S., Noji, T., Bodungen, B. von (1990). What happens to zooplankton faecal pellets? Implications for material flux. Mar. Biol. 104: 15-23

Martens, P. (1978). Faecal pellets. Fich Ident. Zooplankton: $162,4 \mathrm{pp}$

Noji, T. T., Estep, K. W., MacIntyre, F., Norrbin, F. (1991). Image analysis of faecal material grazed upon by three species of copepods. Evidence for coprorhexy, coprophagy and coprochaly. J. mar. biol. Ass. U. K. 71: 465-480

Paffenhöfer, G.-A., Knowles, S. C. (1979). Ecological implications of faecal pellet size, production and consumption by copepods. J. mar. Res. 37: 35-49

Peinert, R., Bathmann, U., Bodungen, B. v., Noji, T (1987). The impact of grazing on spring phytoplankton growth and sedimentation in the Norwegian current. Mitt. geol. paläont. Inst. Univ. Hamb. 62: 149-164

Pilskaln, C. H., Honjo, S. (1987). The faecal pellet fraction of biogeochemical particle fluxes to the deep sea. Global Biogeochem. Cycles 1: 31-48

Schnack, S. B. (1975). Untersuchungen zur Nahrungsbiologie der Copepoden in der Kieler Bucht. Ph. D. thesis, Univ. of Kiel

Schnack, S. B. (1982). The structure of the mouth parts of copepods in Kiel Bay. Meeresforsch. 29: 89-101

Smayda, T. J. (1969) Some measurements of the sinking rate of faecal pellets. Limnol. Oceanogr. 14: 621-625

Smetacek, V.S. (1980). Zooplankton standing stock, copepod faecal pellets and particulate detritus in Kiel Bight. Estuar. coast. mar. Sci. 11: 477-490

Strathmann, R. R. (1967). Estimating the organic carbon content of phytoplankton from cell volume or plasma volume. Limnol. Oceanogr. 12: 411-418

Turner, J. T. (1984a). Zooplankton feeding ecology: content of faecal pellets of the copepod Eucalanus pileatus and Paracalanus quasimodo from continental shelf waters of the Gulf of Mexico. Mar Ecol. Prog. Ser. 15: 27-46

Turner, J. T (1984b). Zooplankton feeding ecology: content of faecal pellets of the copepods Temora turbinata and $T$ stylifera from continental shelf and slope waters near the mouth of the Missisippi River. Mar Biol. 82: 73-83

Turner, J. T (1984c). Zooplankton feeding ecology: contents of faecal pellets of the copepods Acartia tonsa and Labidocera aestiva from continental shelf waters near the mouth of the Missisippi River. P.S.Z.N.I: Mar. Ecol. 5: 265-282

Turner, J. T. (1986). Zooplankton feeding ecology: content of faecal pellets of the copepod Undinula vulgaris from continental shelf waters of the Gulf of Mexico. P.S.Z.N.I: Mar. Ecol. 7: 1-14

Turner, J. T., Ferrante, J. G. (1979). Zooplankton faecal pellets in aquatic ecosystems. Bioscience 29:670-677

Turner, J. T., Tester, P. A. (1989). Zooplankton feeding ecology: nonselective grazing by the copepods Acartia tonsa (Dana), Centropages velificatus (deOliveira), and Eucalanus pileatus (Giesbrecht) in the plume of the Mississippi river. J. exp. mar. Biol. Ecol. 126: 21-34

Urrère, M. A., Knauer, G. A. (1981). Zooplankton faecal pellet fluxes and vertical transport of particulate organic matter in the pelagic environment. J. Plankton Res. 3: 369-387

Utermöhl, H. (1958). Zur Vervollkommnung der quantitativen Phytoplankton Methodik. Mitt. int. Ver. Limnol. 9: 1-38

Zeitzschel, B., Diekmann, P., Uhlmann, L. (1978). A new sediment trap. Mar. Biol. 45: 285-288

Manuscript first received: August 13, 1990

Revised version accepted: June 7, 1991 